DOI: $10.17805 / z p u .2015 .4 .23$

\title{
Productions of Hamlet on the Post-Soviet Stage in Russia*
}

\author{
N. V. ZAKHAROV \\ (MOSCOW UNIVERSITY FOR THE HUMANITIES)
}

The article covers the special role of Shakespeare's Hamlet in Russian culture. As an iconic character Hamlet has a broad scope of application, for instance, he became a feature of Mikhail Vrubel's painting "Hamlet and Ophelia" (1888), and a film by Grigory Kozintsev (1964), etc. Hamlet as a cultural constant has been employed in a great range of original works by Russian authors: Alexander Pushkin, Fyodor Dostoevsky, Leo Tolstoy, Alexander Blok, Vyacheslav Ivanov, Boris Pasternak, etc. The author analyzes some productions of "Hamlet" in Russia of the 1990s-2000s (by Peter Stein, Yuri Butusov, Alexander Titel, Valery Fokin, Vitaly Poplavskiy) as a part of the Shakespearean sphere of national culture, world culture and subcultures and tries to trace down the mechanism of how eighteenth century neo-classical adaptations set a pattern for some of the post-Soviet interpretations of "Hamlet".

Keywords: W. Shakespeare; Shakespeare in Russia; "Hamlet"; Russian culture; post-Soviet productions; Shakespearean sphere

\section{INTRODUCTION}

Tf Shakespeare is considered by Russians to be their own National Poet there is no question that Hamlet should be named a foremost iconic image that is deeply rooted in the very core of Russian culture. It took less than one hundred years for Russians to adopt the image of the Prince of Denmark and begin to consider it as an embodiment of the national character of the social and political form of intellectuals widely known as intelligentsia. One of the reasons for widespread exploration of Hamlet is his everlasting mysterious nature

* Исследование выполнено в рамках проекта «Виртуальная шекспиросфера: трансформации шекспировского мифа в современной культуре», поддержанного грантом РГНФ (№ 14-0300552a).

The paper was prepared as part of the project "Virtual Shakespearean Sphere: Transformations of Shakespearean Myth in Modern Culture" supported with a grant from the Russian Foundation for the Humanities (No. 14-03-00552a). A shorter version of this article was published in the since-discontinued electronic Global Shakespeare Journal (March 2014, vol. 1, issue 2, pp. 179-192) under the title "Hamlet on the Post-Soviet Stage" (www.gsjournal.org). For a reason unknown to us the site has been deleted. Therefore, we decided to update the article and republish it here. 
that has been challenging many writers, critics, directors, actors, painters, musicians, artists of every kind and Shakespeare scholars to comment or interpret this character in their own creative works, personal letters and essays. As part of virtual Shakespearean sphere, Hamlet has inspired a greater body of theories and explanations than any other Shakespearean iconic character discussed in Russian criticism and elsewhere in the world. One can trace the shifts and the progress in theatrical tastes, aesthetic and social theories since the Renaissance just by looking at the bibliography on Shakespeare's Hamlet. Its interpretations show us an enormous variety of textual readings in every possible ways and some of them even go beyond the realm of common sense, including both his cult and its 'decanonization'.

\section{HISTORICAL BACKGROUND}

Shakespeare's Hamlet has always played a special role in Russian culture (see: Bardovsky, 1923; Gibian, 1966; Shekspir i russkaia kul'tura, 1965; Rowe, 1976; Gorbunov, 1985; Levin, 1988; Russian essays ... , 1998; Střibrný, 2000; Zakharov, 2008; Bartoshevich, 2010; Gaydin, 2011; Zakharov, Lukov, 2012). The name of this Shakespearean character first appeared in the Russian press in 1731 thanks to a translation mistake. It was used in the phrase "excellent Hamletic and Othellonian comedies" (Perevod LXI razgovora ..., 1731: 318; cited in: Levin, 1998: 78). The Russian translator simply did not feel the difference between the British playwright and his protagonists. But since the middle of the 18th century, Shakespeare's tragedy has found a vast response among writers and later among readers and theatergoers.

Most of the early nineteenth century Russian translations of Shakespeare were still frequently based on French intermediary versions. One of them was Stepan Viskovatov's translation. The only pre-Romantic vestige in Viskovatov's play was a tinge of gloomy sentimental Gothicism - for instance, the episode when Hamlet walks along the graveyard and plots vengeance while sitting on the tombstone.

Only from the 1820 s on did the Russian literati begin to realize the need for a truthful Shakespeare and new translations appeared; such was, for instance, Mikhail Vronchenko's scholarly translation of Hamlet (1828). His accurate work was, however, deemed unsuitable for the stage.

The Russian Romanticists considered Shakespeare their predecessor and took his artistic model that would help them to find solutions to the problems of their national literature. The achievements of the Russian Romantic translators of Hamlet are especially noteworthy in Nikolai Polevoy's version (1837) that proved to be a turning point. His translation of Hamlet was staged both in Moscow and in Saint Petersburg. This made the tragedy a permanent feature of the Russian theatrical repertoire. It was an inaccurate version, but rather clear for the general public. For the first time ever Shakespeare's characters were speaking on stage in everyday Russian language. Polevoy's translation expressed his generation's dissatisfaction with the contemporary Russian political and cultural situation.

Until the mid-1830s in Russian culture Hamlet was considered to be a strong and singleminded man. In 1838, the leading Russian literary critic of his time Vissarion Belinsky wrote: "Hamlet! $<\ldots .>$ here is the life of man, man himself, you and me, every one of us, more or less, lofty and ridiculous, but always in a sad and pathetic sense" (Belinsky, 1953: 254; cited in: Levin, 1998: 88).

The prominent critic Pavel Annenkov mentioned a contradiction between the aspirations of the progressive youth and political bondage, calling this phenomenon "Russian 
Hamletism". He wrote: "Shakespeare allowed a whole generation of Russian people to feel that they were intelligent human beings capable of comprehending the historical process and the essential conditions of human existence. And all this at a time when indeed a whole generation had no real social integration and no voice, even in the slightest affairs of civil existence" (Annenkov, 1874: 298; cited in: Levin, 1998: 86-87).

If in the 1830s Hamletism was interpreted as 'woe from wit', later, in the 1840s-1860s it was linked to the image of the 'superfluous man': in the new Hamlet they could observe some positive traits, but on the whole, he was pitiful and repulsively unpleasant.

In his essay Hamlet and Don Quixote (1860) Ivan Turgenev expressed a negative attitude towards the "philistine Hamlet" who kept on philosophizing in vain. His interpretation of the Prince of Denmark is also obvious in Hamlet of the Shchigrov Uyezd (1849) and Virgin Soil (1876). Fyodor Dostoevsky used Hamlet's qualities to create literary characters of his own: Ivan Karamazov, Nikolay Stavrogin (in The Possessed), Ippolit (in The Idiot), Versilov (in A Raw Youth) and Aleksey Ivanovich (in The Gambler).

In the 1880s Hamlet's figure was associated with the philosophy of pessimism and inaction. Disapproval eventually led to self-criticism and travesty that brought about new phenomena of quasi-Hamletism. The prototype of those quasi-Hamlets was not Shakespeare's character, but Turgenev's egocentric types like Nezdanov in Virgin Soil. Literary critic Nikolay Mikhailovsky defined those types of characters as "Hamletized piglets".

Since the Revolution of 1917, the Russian Hamlet has experienced many ups and downs. Anatoly Lunacharsky favoured Shakespeare and his lectures on the Bard were permeated with Communist propaganda.

Huge amount of interpretations flourished at that time. For example, psychologist Lev Vygotsky considered Hamlet to be not merely a character, but also a "function of the tragedy". Leonid Pinsky connected Hamlet's image not with the plot development, but with the main subject of the 'great tragedies' - the protagonist's discovery of the real character of the world, where evil is more powerful than it has been imagined by humanists. Many attempts to solve 'Hamlet's question' in the context of Orthodox Christianity were made on the basis of the comparison between Hamlet and Jesus Christ (Konstantin Stanislavsky, Boris Pasternak, Alexander Vannovsky, Andrei Tarkovsky, etc.).

\section{SHAKESPEARE'S HAMLET IN POST-SOVIET CULTURE}

The history of Hamlet in Russia confirms the remarkable flexibility of Shakespeare's iconic images to suit the needs of any age. In the 21st century, Russian literature continues to use the icon of Hamlet in popular culture (commercials, sitcoms etc.), as embodiment of thinker, nobleman, lover, lunatic, and as an enigma. Even today Hamlet remains an outstandingly popular play staged in Russia.

By playing Hamlet, every new generation passes a test on 'damned questions' that the protagonist brings out in his soliloquies. On the whole, the history of post-Soviet productions of Shakespeare's tragedy including performances of Hamlet is "a history of attempts to convert the tragedy into an ironical tragi-farce" (Bartoshevich, 2010: 210; translation is mine. $-N$. Z.). Most productions of Hamlet in the 1990s-2000s can be considered in this manner.

In his stage adaptation of Hamlet (1998) with Russian actors (Eugene Mironov as Hamlet) the prominent German theatre director Peter Stein shifted the scene of action to a boxing ring. Hamlet with an antic crown on his head was playing the saxophone. Fortinbras used to appear wearing a helmet and camouflage gear with an assault rifle in his hands, while 
the First Player was dressed in a female costume with make-up (Vladimir Etush). Hamlet's struggle is represented in a boxing match against the world and himself (see: Zaslavskii, 1998: 7; Murzina, Polianko, Izgarshev, 1999).

At the end of 2005, director Yuri Butusov staged his version of Hamlet at the Moscow Art Theatre. The performance triggered an equivocal reaction among the audience and critics. Yuri Butusov invited talented actors who had earned acclaim in crime TV series (Mikhail Trukhin, Konstantin Khabensky, Mikhail Porechenkov). Butusov's Hamlet appalled the audience with its scenic brilliance. The director and the scene-designer of the performance Alexander Shishkin set the background in a Nordic landscape with an icy sea and a wintered Elsinore. The sea of our times was made of metal trash, wire and empty tin cans: this could be a camp fence or a landfill (Bartoshevich, 2010: 209-216). To the surprise of many theatregoers, Yuri Butusov completely dismissed the character of Horatio. The director emptied his production of well-known secrets and enigmas; he found a simple explanation to everything. An ironical Hamlet, in Butusov's interpretation, is laughing at death and the after world. Shakespeare's Hamlet is trying to understand the mystery of death - there is no such mystery in Butusov's version.

The opera paraphrase of the Shakespeare's tragedy Hamlet (Danish) (Russian) Come$d y$ was likewise conceived in a post-modern manner. A burlesque play based on Shakespeare's motives Hamlet. An Eccentric Comedy in Five Acts (1998) by a Yekaterinburg playwright Arkady Zastyrets was taken as a basis for the libretto. The music was written by composer Vladimir Kobekin. The performance was staged by director Alexander Titel at the Stanislavsky and Nemirovich-Danchenko Moscow Academic Music Theatre (2008). There are almost no topical political allusions common for modern interpretations of Shakespeare (besides an opposition demonstration organized and pre-paid by Laertes), the situation of absurd prevails on the stage mixing the bombastic iambic foot of poetic speech with abstinent invectives. What should one expect from the production when the authors do not task Hamlet with setting right the disjointed time? They shift the emphasis from Hamlet's eternal question 'To be or not to be?' to another one: 'To have or to be?' The stage space of the production turns into a circus where "the whole world is an insane asylum, and Denmark is a loo in the asylum!" The questions what the 'asylum' and the 'loo' are in the post-Soviet space move into the realm of rhetorical questions.

The premiere of Valery Fokin's version of Hamlet at the Russian State Pushkin Academy Drama Theater (St. Petersburg) took place in April, 2010. This production is absolutely dissimilar to the others. It is burning and politic. A sick and desperate Hamlet childishly rebels against the authoritarian principle; he deliriously plays his permanent performance full of grief and madness. Fokin tried to specify the traits of contemporary Hamlets with their frantic longing for truth, antagonism against the fathers' lies, and unwillingness to continue to go on their path. Fokin's production presented a ruthless and painful analysis of contemporary Russian and world history, a complex portrait of modern youth. It is admitted that this interpretation of Hamlet has revived the political theatre in Russia (ibid: 215).

The 450th anniversary of William Shakespeare's birthday saw four première stage productions in Moscow along. One of them proves to be a very modernistic and an extremely experimental. Hamlet/Collage directed by Robert Lepage at the Teatr Natsii (Theatre of Nations) is a mono-performance by gifted Russian actor Yevgeny Mironov who "draws the audience into the whirlwind of fascinating metamorphoses", according to honoured scientist of the Russian Federation, Chairman of the Shakespeare Committee of the Russian Academy of Sciences Alexey Bartoshevich. "Sophisticated computer technologies sit side by 
side with something resembling a simple kaleidoscope. The performance, however, is not a cutting-edge gadget or an exhibit at a Silicon valley trade show, but rather an extremely condensed and tight space where the whole action and all the characters are cramped into" (Bartoshevich, 2014: 235).

In some strange ironical manner these post-Soviet versions of Hamlet inherit the traditions of having the character of the Prince of Denmark staged as 'strong and active' rather than 'weak and Romantic', the traditions that were engrained in Russia in 1748, when Alexander Sumarokov (1717-1777) made his first adaptations of Shakespeare's play in Russia.

Alexander Sumarokov - a Russian poet and dramatist who penned his works in accordance with the rigid patterns and strict rules of classical poetry - published his happy-end version of Hamlet in 1748 (see: Sumarokov, 1970). It was a typical neoclassical tragedy. The theory that Sumarokov followed a French source has been chiefly supported by the conviction that the Russian writer did not know English: "Sumarokov probably used PierreAntoine de La Place's French translation (from Theatre Anglois, 1745-1748) of Shakespeare; there is no evidence that he knew any English" (Gibian, 1966: 728). Though there is no any documented confirmation that Sumarokov knew English at any acceptable level necessary for translation, the latest studies have found evidence that he borrowed an English edition of Shakespeare's plays from the Academic library in 1746-1748. There could have been another source - a German one, since his wife was a native German, but this suggestion lacks reliable evidence. Even if he knew some English, his adaptation of Hamlet is rather an original composition than a translation of any kind. Anyway, there is a strong sense of Shakespeare's presence only in the famous soliloquy 'To be or not to be' (“Что делать мне теперь?"; III, 1) and in the scene of Claudius's kneeling prayer. Thus, one can assume that these are the only two pieces in Sumarokov's version where he relies on the original.

The plot of the play was set according to the neoclassical dramatic rules and general taste of the age of Enlightenment: the supernatural ghost is turned into a prophetical dream; all of the main characters are provided with confidants and confidantes; Gertrude is convinced by Hamlet's rhetoric to admit her wrongs, and mother and son join forces in their revenge on Claudius and Polonius who, in turn, design a plan to assassinate both of them in order for Claudius to be free to marry Ophelia. The most important thing in Sumarokov's vision of Hamlet's characters is that from the beginning to the end, he shows Hamlet as a person of strong will and very determined in his actions. Hamlet escapes all stratagems and deals a crushing blow to his enemies. The resolution was also curious: repenting Gertrude goes to a nunnery, and plotting Polonius commits suicide. The prince becomes the King of Denmark and is to be engaged to his beloved Ophelia, so the whole nation can rejoice.

Sumarokov's Hamlet went through six editions in the 1780s. The play was rather successful on the theatrical stage. The first performance of the play was given in 1750 , where the actors were cadets of the St. Petersburg Land-Gentry Infantry School. It was documented that on July 1, 1757, the first performance was given in St. Petersburg, with a wellknown actor Ivan Dmitrevsky (1734-1821) playing the role of Hamlet. There were several performances but after the early 1760s they stopped. To all appearances, dangerous political parallels with the murder of Peter III in 1762 could have been the reason for it. For example, Soviet scholar Alexander Bardovsky wrote: "For 34 years Russia had witnessed the tragedy of Hamlet in the royal family, and its titular hero had been the prince heir, future Paul I" (Bardovsky, 1923: 142; translation is mine. $-N$. Z.). He also equated Gertrude with Empress Catherine, and Claudius with Count Grigory Orlov. The future Russian Emperor 
Paul I (1796-1801) appreciated Sumarokov's work because he saw in it, not without reason, some similarity with his own fate: in Europe he was referred to as Russian Hamlet. Unfortunately for Russian culture, the practice of political censoring of Hamlet was adopted during the Soviet age, when the play was quite a disturbing issue for Joseph Stalin, who presumably saw in the tragedy a controversial hint at his 'succession' to Vladimir Lenin's power and the shady part that he played in the murder of Lev Trotsky, etc.

Despite the fact that the first Russian Hamlet had very little in common with Shakespeare's original and after its publication and performance all interest in Shakespeare was lost for almost twenty-five years, Alexander Sumarokov's play favourably influenced the formation of a European view on the theatrical art in Russian society. Like the majority of Sumarokov's characters, his Hamlet has no national and historical feature; he speaks the conventional language of pompous classicist drama. However, it was Sumarokov who first introduced the iconic image of Hamlet to the Russian public.

So, this illustrative example of early Russian reception of the greatest play is a very relevant link to the further formation of Shakespeare's reputation. The introduction of the real Shakespeare in Russia (just like in many other European countries) was due to the Romantic Movement that contributed to a Shakespearean cult among its followers.

I must confess that I am not an avid theatre-goer. I am not a dedicated theatre enthusiast, neither am I in deep love with what is happening on modern stage - a constant modernization of the Shakespearean text and drama in Russia. I am a traditionalist by the very sense of this term. In my opinion, something staged in the most bizarre way at the New Globe Theatre is more fitting than any of the Royal Shakespeare Company's experimentations. However, I do love some experiments with authentic texts, which take place every now and then. Therefore, I ought to consider one of the most interesting experiences of that kind.

It was undertaken by the Horizon Theatre-studio ("Gorizont") at the Moscow City Teachers' House in 2010. The stage production was directed by Vitaly Poplavskiy, who is the translator of his own version of Russian Hamlet and a Shakespearean scholar (see, for instance: Smirnova, 2008; Pervushina, 2008). He chose a 200-years-old adaptation of the French intermediary interpretation of Jean-François Ducis (most of the early nineteenth century Russian translations of Shakespeare were still frequently based on French intermediary versions of P. A. de La Place, J. F. Ducis and considerably less often - on German versions), which in turn was reworked by a Russian dramatist Stepan Viskovatov (1786-1831). This neo-classical adaptation of Hamlét (that's how Shakespeare's tragedy was entitled in Viskovatov's translation) was premiè red during the International Conference "Shakespeare Readings 2010". S. Viskovatov's transformation of J. F. Ducis's version of Hamlet (the first stage performance took place in 1810, the printed version was published in 1811) departs from Shakespeare's original in quite a few significant plot details. For instance, the Ghost calls for revenge both on Claudius, who has plotted his murder, and on Gertrude, who has actually committed it; Claudius and Gertrude are lovers, but the Queen refuses to marry the man who has tempted her to kill King Hamlet; the Ghost suffers vividly being devoured by a snake; Claudius is not Hamlet's uncle; the beloved Ophelia is a daughter of Claudius; the Ghost appears in Gertrude's chamber in order not to defend her from Hamlet's anger but to prompt him to kill her; Gertrude constantly feels the need for public confession of her sins and tries to persuade Claudius to do so, and eventually this leads him to killing her; both Hamlet and Ophelia remain alive at the end of the play. All these glaring differences reflect Viskovatov's desire to adapt Shakespeare's play to his perception of neo-classical poetics. 
This means that his main intention was to make the characters' motivations clear for the contemporary Russian public (Poplavskiy, 2010).

A new life was given to Viskovatov's quite outdated text not by changing archaic wording, but rather by bringing so-called psychological intensity in the manner of the psychological theatre of the early 20th century. All these transformations in the very structure of the inner conflict caused significant changes in Hamlet's tragedy. The main conflict of Shakespeare's original play was modified in the context of the aesthetics of neo-classicism, with its idea of public duty and inevitable sacrifices. Although the story of Hamlet lost its philosophical depth, it produced some more dynamic and tight action. One could assume it was a primitive rendering of the complex motives of the original play for the sake of making the story easier for the audience to follow the characters' motivation, but basically the domestic conflict between Hamlet's duty to bring order to the state of Denmark and kill his sweetheart's father and his love is filled with some universal dimension of truly dreadful sense of Ophelia's tragedy.

The actors (V. Novikov, T. Andreeva, A. Kichik, K. Muradian, A. Takadzhan, J. Nagle, M. Dodzin) deserve special praise; they astonished the audience with their stage presence and incredible ability to pronounce the ancient text. Viskovatov's text apparently was intended for a bombastic and pompous declamation, but it was delivered naturally, with passion and feelings, so the audience completely lost the sense of archaic essence of Viskovatov's works. On the contrary, the amazingly vivid beauty of these old words was clear for everyone who witnessed the action. Moreover, V. Poplavskiy, who is always sensitive to the melodramatic nature of every literary work, just discovered the right mode for his stage performance - visually discreet, precise, as if he had to animate a book's pages (Pervushina, 2010: 381).

\section{CONCLUSIONS}

Such experimentations based on archaic vocabulary and on the very first examples of Shakespeare's reception in Russia are rather few. An attempt to stage Alexander Sumarokov's version of Hamlet (1748) was made by the pupils of one of the Russian lyceums several years ago. Meanwhile, such low-budget dramatic experiments have a very important and significant potential. They give actors an authentic opportunity to reproduce the historical age when Shakespeare had not yet become the cultural idol he is today. Such productions let the theatre-goers feel the evolutional process that the tragedy of Hamlet has undergone in the Russian cultural and aesthetic reception.

Among the various twenty-first century productions of Hamlet on the post-Soviet stage it is particularly necessary to note that they fail to outshine the previous ones, presented on Russian and Soviet stages at: the Moscow Art Theatre (1911), the Vakhtangov Theatre (1932), S. Radlov's Leningrad Theatre-studio (1938), the A. Pushkin Leningrad Academic Drama Theatre (1954), the Mayakovsky Moscow Academic Theatre (1954), Taganka Theatre (1971), etc.

Nevertheless, even in spite of the diagnosis provided by the outstanding theatre historian and Shakespeare scholar Alexey Bartoshevich - "our time, at least in Russia, is not for this play" (Bartoshevich, 2010: 211; translation is mine. - N. Z.) - Hamlet is still sparking a permanent interest among Russian audience. Directors continue to stage it and any selfrespecting actor dreams of appearing as the Prince of Denmark on stage or screen. This eternal play transcends time, popular tastes, economic reforms, and political environment which provide endless examples for the Shakespearean sphere studies of modern culture. 


\section{REFERENCES}

Annenkov, P. V. (1874) Aleksandr Sergeevich Pushkin v Aleksandrovskuiu epokbu. 1799-1826 gg. [Alexander Sergeevich Pushkin in the Alexander age. 1799-1826]. St. Petersburg. M. Stasiulevich's Printing House. VIII, 332, [2] p. (In Russ.).

Bardovsky, A. A. (1923) Russkii Gamlet [Russian Hamlet]. In: Russkoe prosbloe. Istoricheskie sborniki [Russian past. Historical collections]. Bk. 4 / ed. by S. F. Platonov, A. E. Presniakov and Ju. Gessen. Petrograd ; Moscow, Petrograd Publ. Pp. 135-145. (In Russ.).

Bartoshevich, A. V. (2010) Gamlety nashikh dnei [Hamlets of our time]. In: Shekspirovskie chteniia [Shakespeare readings]/ ed. by A. V. Bartoshevich. Moscow, Moscow University for the Humanities Publ. 404 p. Pp. 209-216. (In Russ.).

Bartoshevich, A. V. (2014) Khronika shekspirovskogo goda [A chronicle of the Shakespeare year]. Znanie. Ponimanie. Umenie, no. 2, pp. 224-235. (In Russ.).

Belinsky, V. G. (1953) «Gamlet», drama Shekspira. Mochalov v roli Gamleta ["Hamlet", Shakespeare's drama. Mochalov as Hamlet]. In: Belinsky, V. G. Polnoe sobranie sochinenii [Complete works] : in 13 vols. Moscow, Publ. House of the Academy of Sciences of the USSR. Vol. 2. 767 p. Pp. 253-345. (In Russ.).

Gaydin, B. N. (2011) Vechnye obrazy kak konstanty kul'tury: tezaurusnyi analiz "gamletovskogo voprosa" [Eternal images as constants of culture: A thesaurus analysis of the "Hamlet's question"] : Monograph. Saarbrücken, Lambert Academic Publishing. 212 p. (In Russ.).

Gibian, G. (1966) Russia. In: A Shakespeare encyclopaedia / ed. by O. J. Campbell and E. G. Quinn. London; New York, Methuen \& Co LTD. 1014 p. P. 728.

Gorbunov, A. N. (1985) K istorii russkogo «Gamleta» [On the history of Russian "Hamlet"]. In: Shakespeare, W. Gamlet [Hamlet] : Selected translations. Moscow, Raduga Publ. 640 p. Pp. 7-26. (In Russ.).

Levin, Yu. D. (1988) Shekspir i russkaia literatura XIX veka [Shakespeare and 19th century Russian literature]. Leningrad, Nauka Publ. 327 p. (In Russ.).

Levin, Yu. D. (1998) Shakespeare and Russian literature: Nineteenth-century attitudes. In: Russian essays on Shakespeare and bis contemporaries / ed. by A. T. Parfenov and J. G. Price. Newark, NJ, University of Delaware Press ; London, Associated University Presses. 209 p. Pp. 78-96.

Murzina, M., Polianko, P. and Izgarshev, I. (1999) Russkii mal'chik po imeni Gamlet [Russian boy named Hamlet]. Argumenty i fakty, May 27, no. 21. (In Russ.).

Perevod LXI razgovora iz I chasti Spektatora [Translation of the 61st conversation from the 1st part of The Spectator]. (1731) In: Mesiacbnye istoricheskie, genealogicheskie i geograficheskie primechaniia $v$ "Vedomostiakb» [Monthly historical, genealogical and geographical notes to "The Vedomosty"]. St. Petersburg, Printing House of the Academy of Sciences. Pt. XXVIII. P. 318. (In Russ.).

Pervushina, E. A. (2008) "Pust' uznaet mir o tom, chto znaiu... lish' ia odin" ("Gamlet" Shekspira v postanovke Vitaliia Poplavskogo) ["And let me speak to the yet unknowing world... How these things came about”. Shakespeare's "Hamlet” dir. by Vitaly Poplavskiy]. In: Shekspirovskie shtudii X [Shakespeare studies X] : Shakespeare Readings 2008: Proceeding of the International conference (Moscow, September 29 - October 3, 2008)/ ed. by N. V. Zakharov and Vl. A. Lukov. Moscow, Moscow University for the Humanities Publ. 90 p. Pp. 79-84. (In Russ.).

Pervushina, E. A. (2010) «Shekspirovskie chteniia» 2010 [Shakespeare Readings 2010]. In: Shekspirovskie chteniia [Shakespeare Readings]/ ed. by A. V. Bartoshevich. Moscow, Moscow University for the Humanities Publ. 404 p. Pp. 378-385. (In Russ.).

Poplavskiy, V. R. (2010) Tragediia o Gamlete v estetike Renessansa i klassitsizma [Tragedy of Hamlet in renaissance and classicist aesthetics]. In: Shekspirovskie cbteniia [Shakespeare Readings]/ ed. by A. V. Bartoshevich. Moscow, Moscow University for the Humanities Publ. 404 p. Pp. 196-203. (In Russ.).

Rowe, E. (1976) Hamlet: A window on Russia. New York, New York University Press. 186 p.

Russian essays on Shakespeare and his contemporaries (1998) / ed. by A. T. Parfenov and J. G. Price. Newark, NJ, University of Delaware Press ; London, Associated University Presses. 209 p. 
Shekspir i russkaia kul'tura [Shakespeare and Russian culture] (1965) / ed. by M. P. Alekseev. Moscow, Nauka Publ. 823 p. (In Russ.).

Smirnova, N. A. (2008) Gamlet na gorizonte... [Hamlet on the horizon...]. In: Shekspirovskie shtudii $X$ [Shakespeare studies X] : Shakespeare Readings 2008: Proceeding of the International conference (Moscow, September 29 - October 3, 2008) / ed. by N. V. Zakharov and Vl. A. Lukov. Moscow, Moscow University for the Humanities Publ. 90 p. Pp. 77-79. (In Russ.).

Střibrný, Z. (2000) Shakespeare and Eastern Europe. Oxford; New York, Oxford University Press. $161 \mathrm{p}$.

Sumarokov, A. P. (1970) Selected tragedies of A. P. Sumarokov/ transl. by Richard and Raymond Fortune ; introd. by J. Fizer. Evanston, Northwestern University Press. 229 p.

Zakharov, N. V. (2008) Shekspirizm russkoi klassicbeskoi literatury: tezaurusnyi analiz [Shakespearianism of Russian classical literature: The thesaurus analysis] / ed. by Vl. A. Lukov ; Moscow University for the Humanities. The Institute of Fundamental Applied Studies; The International Academy of Science. Moscow, Moscow University for the Humanities Publ. 320 p. (In Russ.).

Zakharov, N. V. and Lukov, Vl. A. (2012) Genii na veka: Sbekspir v evropeiskoi kul'ture [A Genius for centuries: Shakespeare in European culture]. Moscow, Humanities Institute of TV \& Radio Broadcasting Publ. 504 p. (In Russ.).

Zaslavskii, G. (1998) Neskol'ko kapel' krovi. Prem'era «Gamleta» Petera Shtaina [Several drops of blood. The opening night of Peter Stein's "Hamlet"]. Nezavisimaia gazeta, October 14, no. 191, p. 7 (In Russ.).

Submission date: 9.08 .2015 .

\section{ПОСТАНОВКИ «ГАМАЕТА» НА ПОСТСОВЕТСКОЙ СЦЕНЕ РОССИИ \\ H. B. ЗАХАРOB \\ (МОСКОВСКИЙ ГУМАНИТАРНЫЙ УНИВЕРСИТЕТ)}

Шекспировский Гамлет давно стал вечным образом в мировой культуре. Он получил оригинальное выражение в русской литературе, театре, живописи, музыке, кинематографе: в сочинениях и работах А. С. Пушкина, Ф. М. Аостоевского, И. С. Тургенева, $\Lambda$. Н. Толстого, М. А. Врубеля, А. А. Блока, Вяч. И. Иванова, Б. А. Пастернака, Г. М. Козинцева и др.

В статье рассматривается особая роль шекспировского «Гамлета» в русской культуре последних десятилетий, анализируются некоторые постановки пьесы в России 1990-2000-х годов (П. Штайна, Ю. Н. Бутусова, А. Б. Тителя, В. В. Фокина, В. Р. Поплавского). Среди постсоветских интерпретаций пьесы Шекспира доминируют режиссерские переделки «Гамлета». Их особенности являются предметом изучения автора статьи.

Ключевые слова: У. Шекспир; Шекспир в России; «Гамлет»; русская культура; постсоветские постановки; шекспиросфера

\section{СПИСОК АИТЕРАТУРЫ}

Анненков, П. В. (1874) Александр Сергеевич Пушкин в Александровскую эпоху. 1799-1826 гг. СПб. : Тип. М. Стасюлевича. VIII, 332, [2] с.

Бардовский, А. А. (1923) Русский Гамлет // Русское прошлое. Исторические сборники. Кн. 4 / под ред. С. Ф. Платонова, А. Е. Преснякова, Ю. Гессена. Пг. ; М. : ИзА-во «Петроград». C. 135-145.

Бартошевич, А. В. (2010) Гамлеты наших дней // Шекспировские чтения. Науч. совет РАН «История мировой культуры»/ гл. ред. А. В. Бартошевич. М. : ИзА-во Моск. гуманит. ун-та. 404 с. C. 209-216.

Бартошевич, А. В. (2014) Хроника шекспировского года // Знание. Понимание. Умение. № 2. C. 224-235.

Белинский, В. Г. (1953) «Гамлет», драма Шекспира. Мочалов в роли Гамлета // Белинский В. Г. Полн. собр. соч. : в 13 т. М. : ИзА-во АН СССР. Т. 2.767 с. С. 253-345. 
Гайдин, Б. Н. (2011) Вечные образы как константы культуры: тезаурусный анализ «гамлетовского вопроса» : монография. Saarbrücken : Lambert Academic Publishing. 212 c.

Горбунов, А. Н. (1985) К истории русского «Гамлета»// Шекспир У. Гамлет : Избр. переводы. М. : Радуга. 640 с. С. 7-26.

Заславский, Г. (1998) Несколько капель крови. Премьера «Гамлета» Петера Штайна // Независимая газета. 14 октября. № 191. С. 7.

Захаров, Н. В. (2008) Шекспиризм русской классической литературы: тезаурусный анализ / отв. ред. Вл. А. Ауков. М. : Изд-во Моск. гуманит. ун-та. 320 с.

Захаров, Н. В., Ауков Вл. А. (2012) Гений на века: Шекспир в европейской культуре : монография. М. : ГИТР. 504 с.

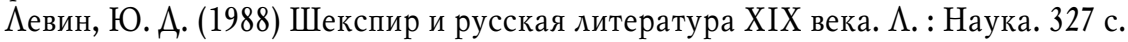

Мурзина, М., Полянко, П., Изгаршев, И. (1999) Русский мальчик по имени Гамлет // Аргументы и факты. 27 мая. № 21.

Первушина, Е. А. (2010) «Шекспировские чтения» 2010 года // Шекспировские чтения. Науч. совет РАН «История мировой культуры»/ гл. ред. А. В. Бартошевич. М. : ИзА-во Моск. гуманит. ун-та. 404 с. С. 378-385.

Первушина, Е. А. (2008) «Пусть узнает мир о том, что знаю... лишь я один» («Гамлет» Шекспира в постановке Виталия Поплавского) // Шекспировские штудии X : Шекспировские чтения 2008. Материалы международной научной конференции (Москва, 29 сентября - 3 октября 2008 года)/ отв. ред. Н. В. Захаров, Вл. А. Ауков; Моск. гуманит. ун-т. Ин-т фундамент. и прикл. исследований. М. : ИзА-во Моск. гуманит. ун-та. 90 с. С. 79-84.

Перевод LXI разговора из I части Спектатора (1731)// Месячные исторические, генеалогические и географические примечания в «Ведомостях». СПб. : Тип. Академии наук. Ч. XXVIII. C. 318.

Поплавский, В. Р. (2010) Трагедия о Гамлете в эстетике Ренессанса и классицизма // Шекспировские чтения. Науч. совет РАН «История мировой культуры» / гл. ред. А. В. Бартошевич. М. : Изд-во Моск. гуманит. ун-та. 404 с. С. 196-203.

Смирнова Н. А. Гамлет на горизонте...// Шекспировские штудии X : Шекспировские чтения 2008. Материалы международной научной конференции (Москва, 29 сентября - 3 октября 2008 года) / отв. ред. Н. В. Захаров, Вл. А. Ауков ; Моск. гуманит. ун-т. Ин-т фундамент. и прикл. исследований. М. : ИзА-во Моск. гуманит. ун-та. 90 с. С. 77-79.

Шекспир и русская культура (1965) / под ред. М. П. Алексеева. М. ; А. : Наука. 823 с.

Gibian, G. (1966) Russia // A Shakespeare encyclopaedia/ ed. by O. J. Campbell, E. G. Quinn. L. ; N. Y. : Methuen \& Co LTD. 1014 p. P. 728.

Levin, Yu. D. (1998) Shakespeare and Russian literature: Nineteenth-century attitudes // Russian essays on Shakespeare and his contemporaries / ed. by A. T. Parfenov, J. G. Price. Newark, NJ : University of Delaware Press ; L. : Associated University Presses. 209 p. Pp. 78-96.

Rowe, E. (1976) Hamlet: A window on Russia. N. Y. : New York University Press. 186 p.

Russian essays on Shakespeare and his contemporaries (1998) / ed. by A. T. Parfenov, J. G. Price. Newark, NJ : University of Delaware Press ; London : Associated University Presses. 209 p.

Střibrný, Z. (2000) Shakespeare and Eastern Europe. Oxford ; N. Y. : Oxford University Press. $161 \mathrm{p}$.

Sumarokov, A. P. (1970) Selected tragedies of A. P. Sumarokov/ transl. by Richard and Raymond Fortune ; introd. by J. Fizer. Evanston : Northwestern University Press. 229 p.

Аата поступления: 9.08.2015 2.

Захаров Николай Владимирович - доктор философии $(\mathrm{PhD})$, кандидат филологических наук, директор Центра теории и истории культуры Института фундаментальных и прикладных исследований Московского гуманитарного университета, ученый секретарь Шекспировской комиссии РАН. Адрес: 111395, Россия, г. Москва, ул. Юности, д. 5, корп. 6. Тел.: +7 (499) 374-75-95. Эл. aspec: nikoltine@yandex.ru 
Zakharov Nikolay Vladimirovich, Candidate of Philology, PhD, Director, Center for the Theory and History of Culture, Institute of Fundamental and Applied Studies, Moscow University for the Humanities; Academic Secretary, Shakespeare Committee of the Russian Academy of Sciences. Postal address: Bldg. 6, 5 Yunosti St., 111395 Moscow, Russian Federation. Tel.: +7 (499) 374-75-95. E-mail: nikoltine@yandex.ru 